\title{
Resveratrol as a protective agent of goat sperm submitted to sex sorting in discontinuous Percoll gradient - preliminary results
}

\author{
Ellen CB Silva ${ }^{1 *}$, Helder M Souza', Lúcia CP Arruda', Chirlane C Silva², Daniela S Carvalho', \\ Maria Madalena P Guerra ${ }^{1}$ \\ From 5th Congress of the Brazilian Biotechnology Society (SBBIOTEC) \\ Florianópolis, Brazil. 10-14 November 2013
}

\section{Background}

Sexing sperm is an important biotechnical that enables improve animal production, with achievement of maximum animal breeding. However, all sex semen methodologies can promote irreparable damages to sperm cell, which compromise their fertility [1]. Among the main causes of injures to the sperm are the reactive oxygen species, which have their production intensified during semen manipulation [2]. Therefore, antioxidants therapies can be an important alternative to protect the sperm during laboratory manipulation [3]. Thus, as resveratrol is a powerful antioxidant with an important role on sperm protection [3], the aim of this study was to evaluate the protective effect of resveratrol on goat sperm submitted to sex sorting in discontinuous Percoll gradient.

\section{Methods}

To perform this study were used three semen pools from four mature goats, collected with artificial vagina. The fresh semen pools (G1) were analyzed and diluted in 10X DMEM to $800 \times 10^{6}$ sperm $/ \mathrm{mL}$. Aliquots of $500 \mu \mathrm{L}$ of the diluted semen were added on Percoll discontinuous gradients, and prepared according Resende et al. [4], without (G2=sexed semen) or with resveratrol $(G 3=$ sexed semen + $75 \mu \mathrm{M}$ resveratrol). After that, the gradients added of the semen samples were centrifuged $(500 \times$ g per $20 \mathrm{~min})$ and the pellet of cell recovered. The spermatic cells recovered from each gradient, with or without resveratrol, were evaluated too. The Sperm parameters accessed were plasma membrane integrity (PMi) by CFDA and PI [5], mitochondrial membrane potential (MMP) by JC-1 [5], total motility (TM) and progressive motility (PM) by CASA. Statistical analysis was done with ANOVA and Teste-t at $5 \%$ significance.

\section{Results and conclusions}

The percentage of spermatic cells with PMi was higher to $\mathrm{G} 1(\mathrm{P}<0.05)$ than to $\mathrm{G} 2\left(\mathrm{G} 1=83.00 \pm 5.07^{\mathrm{a}} ; \mathrm{G} 2=\right.$ $\left.67.83 \pm 0.76^{\mathrm{b}} ; \mathrm{G} 3=76.50 \pm 4.82^{\mathrm{ab}}\right)$. No statistics differences $(P>0.05)$ were observed between all the experimental groups for +MMP $(\mathrm{G} 1=87.33 \pm 8.31$; G2 = $76.50 \pm 17.32 ; \mathrm{G} 3=87.17 \pm 9.00), \mathrm{TM}(\mathrm{G} 1=84.73 \pm$ $7.12 ; \mathrm{G} 2=71.50 \pm 18.70 ; \mathrm{G} 3=78.43 \pm 7.98)$ and $\mathrm{PM}$ $(\mathrm{G} 1=37.35 \pm 6.67 ; \mathrm{G} 2=39.99 \pm 12.41 ; \mathrm{G} 3=48.61 \pm$ 10.12). Nevertheless, sexed semen with resveratrol showed numerically, higher values to the parameters evaluated than without it, fact that consolidates the Sarlós et al. [3] observations about the protective effect of resveratrol. In conclusion, resveratrol does not represent protection to goat sperm submitted to sex sorting in discontinuous Percoll gradient. However, new studies should be realized to reduce the standard variances and determine the real role of resveratrol on sperm protection.

\section{Acknowledgements \\ The authors are grateful to FACEPE, CAPES, RENORBIO and CNPq \\ Authors' details \\ ${ }^{1}$ Laboratório de Andrologia - Universidade Federal Rural de Pernambuco, Recife, PE, 52171-900, Brazil. 'Laboratório de Enzimologia - Universidade Federal de Pernambuco, Recife, PE, 50670-901, Brazil.}

Published: 1 October 2014 


\section{References}

1. Hossepian de Lima VFM: Avanços metodológicos na seleção do sexo de espermatozóides bovinos para utilização no melhoramento genético e na produção animal. $R$ Bras Zootec 2007, 36:219-228.

2. Silva $E C B$, Guerra MMP: Espécies reativas de oxigênio e nitrogênio: produção e efeitos sobre a integridade estrutural e funcional dos espermatozoides. Ciênc Vet Tróp 2010, 13:9-16.

3. Sarlós P, Molnár A, Kókai M, Gábor G, Rátky J: Comparative evaluation of the effect of antioxidants in the conservation of ram semen. Acta Vet Hung 2002, 50:235-45.

4. Resense MV, Lúcio AC, Perini AP, Oliveira LZ, Almeida AO, Gusmão AL, Lima VFMH: Desvio da proporção de sexo e integridade do DNA dos espermatozoides bovinos centrifugados em gradientes de densidade contínuos. Rev Bras Saúde Prod Na 2010, 11:260-269.

5. Silva ECB, Cajueiro JFP, Silva SV, Soares PC, Guerra MMP: Effect of antioxidants resveratrol and quercetin on in vitro evaluation of frozen ram sperm. Theriogenology 2012, 77:1722-1726.

doi:10.1186/1753-6561-8-S4-P149

Cite this article as: Silva et al:: Resveratrol as a protective agent of goat sperm submitted to sex sorting in discontinuous Percoll gradient preliminary results. BMC Proceedings 2014 8(Suppl 4):P149.

\section{Submit your next manuscript to BioMed Central} and take full advantage of:

- Convenient online submission

- Thorough peer review

- No space constraints or color figure charges

- Immediate publication on acceptance

- Inclusion in PubMed, CAS, Scopus and Google Scholar

- Research which is freely available for redistribution

Submit your manuscript at www.biomedcentral.com/submit 